\title{
ADVERSE INFERENCES IN NLRB ADJUDICATION
}

In $U A W$ v. $N L R B^{1}$ the Court of Appeals for the District of Columbia Circuit, reversing and remanding the NLRB's dismissal of an unfair labor practice complaint, ${ }^{2}$ ordered the NLRB to draw an evidentiary adverse inference against the employer-respondent based on his unexplained failure to produce records which might have resolved the factual controversy before the Board. In 1963, the UAW began an organizing campaign to umionize the Gyrodyne Company of America. As the campaign gained strength, however, the company began to discharge union-meinber employees. The union sought redress before the NLRB, alleging that the employees had been fired for their union activity in violation of section 8 of the National Labor Relations Act (NLRA). ${ }^{3}$ Denying this charge, the company contended that the employees had lost their jobs as part of an overall cost-cutting campaign. ${ }^{4}$ In an attempt to refute the cost-cutting defense during the preliminary hearing, the General Counsel of the NLRB subpoenaed various coinpany records which, he alleged, would show that the discharged employees had been replaced. Despite the subpoena, hiring records were never produced; ${ }^{5}$

1. 459 F.2d 1329 (D.C. Cir. 1972).

2. Gyrodyne Co. of America, Inc., 185 N.L.R.B. No. 133, 75 L.R.R.M. 1238 (1970) (supplemental decision), aff'g 170 N.L.R.B. 236 (1968).

3. 29 U.S.C. $\S \S 158(a)(1),(3)(1970)$. Section 8 provides in part:

(a) It shall be an unfair labor practice for an einployer-

(1) to interfere with, restrain, or coerce employees in exercise of the rights guaranteed in section 157 of this title;

(3) by discrimination in regard to hire or tenure of employinent or any term or condition of employinent to encourage or discourage membership in any labor organization ....

4. The president of Gyrodyne indicated that he had instituted a general costcutting program in response to letters from President Johnson and Defense Secretary McNamara urging him to cnt costs. 459 F.2d at 1333.

5. Neither the court opinion nor the NLRB opinions explain why the subpoena was not enforced. Typically, if the person served with a subpoena does not comply, neither the trial examiner, the Board, nor the NLRB Regional Director can compel obedience; rather, the Board must petition the appropriate federal district court for an order. 29 U.S.C. $\S 161(2)(1970)$. The person who refuses to obey the subpoena is given notice and may appear in court to defend his non-compliance. If an order directing compliance with the subpoena is issued by the court, subsequent failure to comply may be punished as contempt of court. 1 B. WeRNe, LABOR RELA- 
the employer did, however, turn over other records dealing with the discharges and gave oral testimony on the matter as well. The trial examiner, finding the employer's testimony reliable and trustworthy, attached no adverse inference to the failure to produce the hiring records. The Board, in adopting the examiner's findings, drew no adverse inference of its own from the non-production of the hiring records, and dismissed the complaint. ${ }^{6}$ The union appealed to the Court of Appeals for the District of Columbia Circuit, ${ }^{7}$ arguing inter alia ${ }^{8}$ that an adverse inference should have been drawn from the failure to produce records. Although not agreemg entirely with this contention, the court remanded the case for the Board alternatively to explain its failure to draw the inference, to draw the inferences and reconsider its decision, or to require production of the records. ${ }^{\circ}$ In a supplemental decision, the NLRB affirmed its prior decision to dismiss the complaint, ${ }^{10}$ again refusing to attach an adverse inference to the company's failure to produce all the hiring records. The Board found that: (1) the employer's testimony was reliable and trustworthy; (2) the missing subpoenaed materials were not important; and (3) the personnel files, if produced, would not necessarily establish that the discharges were reprisals for the

TIONS LAW \& Practice $\$ 8.51$ (1966). Compare Fed. R. Crv. P. 37 which provides sanctions for failure to make discovery. A party attempting to evade discovery may be subjected to a variety of sanctions including an order (1) requiring that certain facts be taken to be estabhished, (2) refusing to allow the disobedient party to support or oppose designated claims or defenses, (3) dismissing all or part of the action, (4) rendering a judgment by default, or (5) assessing costs and attorneys' fees. If a deponent fails to be sworn in or to answer a question after being directed to do so by the court, the failure may be considered a contempt of court. See C. Wright, LaW of Federal Courts $\$ 90$ ( $2 \mathrm{~d}$ ed. 1970).

The reason for the General Counsel's failure to avail himself of the opportunity to secure judicial enforcement of the subpoena was, apparently, his rehance on the statement of the trial examiner that "I will draw my own inferences from the refusal" to produce the subpoenaed documents. Brief for Petitioner at 16, UAW v. NLRB, 459 F.2d 1329 (D.C. Cir. 1972). Another factor in the General Counsel's failure to utilize the judicial enforcement procedure was apparently the fact that the procedure is "extraordinarily time consuming." $I d$.

6. Gyrodyne Co. of America, Inc., 170 N.L.R.B. 236 (1968).

7. UAW v. NLRB, 419 F.2d 686 (D.C. Cir. 1969).

8. The union also argued that the refusal of the trial examiner to admit evidence of Gyrodyne's behavior during another union campaign 18 months before was prejudicial error. The court held that the trial examiner's decision was proper. Id. at 687 .

9. Id.

10. Gyrodyne Co. of America, Inc., 185 N.L.R.B. No. 133, 75 L.R.R.M. 1238 (1970) (supplemental decision). 
employees' union activity. ${ }^{11}$ The union, dissatisfied with the Board's refusal to draw the inference, again sought review in the D.C. Circuit which reversed and remanded the action to the NLRB, ordering it to draw an adverse inference.

The adverse inference rule, a corollary to the general concept of inferences, ${ }^{12}$ provides that where a party fails to produce evidence within his control which is relevant to an issue in controversy, the trier of fact inay infer that the evidence, if produced, would be unfavorable to that party. ${ }^{13}$ The policy underlying the use of the adverse inference rule is the achievement of an equitable decision made on the basis of all relevant evidence. Upon the failure of a party to produce pertinent evidence without adequate explanation, the conclusion may be drawn that the withheld evidence is unfavorable; therefore, the inference is permitted in order to prevent a recalcitrant party froin profiting by his own wrongdoing. The rule, utilized as a rule of evidence in a variety of proceedings, is ordinarily viewed as discretionary in nature. ${ }^{14}$ While the rule is also

11. 75 L.R.R.M. at $1239-40$.

12. An inference is a proposition, deduction, or conclusion which reason and logic lead the trier of fact to draw from established facts. See, e.g., State v. Jones, 39 N.M. 395, 401, 48 P.2d 403, 406 (1935) ("An inference is merely a logical deduction from facts and evidence."); State v. Nevius, 147 Ohio St. 263, 274, 71 N.E.2d 258, 265 (1947) ("An 'inference' is a conclusion, which by means of data founded upon common experience, natural reason draws from facts which are proved."); Peterson v. Betts, 24 Wash. 2d 376, 393, 165 P.2d 95, 104 (1946) ("An inference is a logical deduction or conclusion from an established fact.").

13. Interstate Circuit, Inc. v. United States, 306 U.S. 208, 226 (1939); P.R. Mallory \& Co. v. NLRB, 400 F.2d 956, 959 (7th Cir. 1968); Maphis Chapman Corp. v. NLRB, 368 F.2d 298, 304 (4th Cir. 1966); South, Inc. v. Moran Towing \& Transp. Co., 252 F. Supp. 500, 507 (S.D.N.Y. 1965), aff'd, 360 F.2d 1002 (2d Cir. 1966). See 2 J. Wigmore, Treatise on Evidence $\$ 285$ (3d ed. 1940). See also 1 B. JONES, THE LAW OF EVIDENCE \& 28 (5th ed. 1958).

An adverse inference may arise in a variety of circumstances: when a party fails to call a witness, fails to take the stand as a witness himself, or fails to produce as evidence writings or objects in his possession. C. MCCormICK, LAw of EvIDENCE \& 272 (2d ed. 1972). The failure to produce evidence in defiance of a subpoena would appear to be a strong reason for drawing the inference. See note 40 infra and accompanying text.

14. The permissive nature of the adverse inference rule has been indicated in administrative law cases involving NLRB decisions. In NLRB v. Ford Radio \& Mica Corp., 258 F.2d 457 (2d Cir. 1958), the court, in denying enforcement of a Board reinstatement order, discussed the value of the testimony of a policeman who witnessed activity of discharged employees and communicated his findings to the employer. The court stated:

The contents of this communication were not brought out. However, since proof of motivation of the employer was part of the General Coun- 
utilized by other administrative agencies, ${ }^{15}$ it is implicitly available in NLRB proceedings which inust be conducted, so far as practicable, in accordance with the rules of evidence utilized in the federal district courts. ${ }^{16}$ Furthermore, the authority to draw any inferences froin the facts has been expressly placed by Congress exclusively in the Board ${ }^{17}$ and has been affirmed in case law. ${ }^{18}$

sel's case, his refusal to elicit this readily available and crucial testimony of a distinterested witness may well be taken to mean that the information was adverse to his case. Id. at 463 (emphasis added).

In NLRB v. Wallick, 198 F.2d 477 (3d Cir. 1952), business partners were accused of an unfair labor practice in closing their plant upon liearing that employees were joining the union. The court indicated:

The trial examiner noted that respondents had failed to adduce evidence as to their profit-loss position. This evidence was vital and it was clearly within respondents' power to produce it. The Board would have been warranted in drawing an inference that such evidence, if adduced, would not have been favorable to respondents. Id. at 483 (emphasis added).

In Crowe Gravel Co., 168 N.L.R.B. 1040 (1967), the trial examiner held that employees were discharged because of their union membership in violation of the NLRA. In response to the employer's defense that the discharges were economically motivated, the trial examiner indicated:

The failure to offer such evidence, [of the alleged change in the nature of sales] especially when viewed in the light of the unreliability of [the ennployer's] testimony, permits the inference, which is made . . . (einphasis added). Id. at 1047.

Cf. Maphis Chapman Corp. v. NLRB, 368 F.2d 298 (4th Cir. 1966); NLRB v. Entwistle Mfg. Co., 120 F.2d 532 (4th Cir. 1941).

The permissive nature of the adverse inference rule has been indicated in civil law cases as well. See, e.g., Teamsters Local 167 v. United States, 291 U.S. 293, 298 (1934) ("justly may be inferred"); Bray v. United States, 306 F.2d 743, 747 (1967) ("jury is permitted bnt not compelled") (emphasis in original); United States v. Roberson, 233 F.2d 517, 519 (5th Cir. 1956) (failure to offer evidence "may in a proper case be considered as a circumstance against him"); Washington Gas Light Co. v. Biancaniello, 183 F.2d 982, 985 (1950) ("permits the inference"); Austerberry v. United States, 169 F.2d 583, 593 (6th Cir. 1948) ("justified in concluding"); Borkovic v. Pennsylvania R.R., 180 F. Supp. 495, 501 (W.D. Pa. 1960) ("the jnry may infer"). See note 34 infra. See generally 1 B. JoNES, supra note 13, $\S 28$; C. MCCORMICK, supra note 13, $\$ 272 ; 2$ J. WIGMORE, supra note 13, 285.

15. N. Sims Organ \& Co. v. SEC, 293 F.2d 78, 80 (2d Cir. 1961); Evis Mfg. Co. v. FTC, 287 F.2d 831, 847 (9th Cir. 1961).

16. Any such proceeding shall, so far as practicable, be conducted in accordance with the rules of evidence applicable in the district courts of the United States under the rules of civil procedure for the district courts of the United States, adopted by the Supreme Court of the United States pursuant to section 2072 of Title 28. 29 U.S.C. $\$ 160(\mathrm{~b})(1970)$.

17. "The findings of the Board with respect to questions of fact if supported by substantial evidence on the record considered as a whole shall be conclusive." Id. $\S 160(\mathrm{e})$.

18. NLRB v. Link-Belt Co., 311 U.S. 584, 597 (1940) ("Congress entrusted the Board, not the Courts with the power to draw inferences from the facts."); NLRB v. Falk Corp., 308 U.S. 453, 461 (1940); NLRB v. Pennsylvania Greyliound Lines, 303 U.S. 261, 270 (1938); NLRB v. Sequoyah Mills, Inc., 409 F.2d 606, 609 
When reviewing NLRB proceedings, courts are limited to determining whether or not the agency decision rests upon substantial evidence. $^{19}$ Section 10 (e) of the NLRA provides that when a court reviews an order of the Board, [t] he findings of the Board with respect to questions of fact if supported by substantial evidence on the record considered as a whole shall be conclusive."20 This section has been construed to mean that a reviewing court must not displace the Board's choice between two conflicting views, but can only set aside a Board decision when

it cannot conscientiously find that the evidence supporting that decision is substantial, when viewed in the light that the record in its entirety furnishes, including the body of evidence opposed to the Board's view. ${ }^{21}$

Thus, an NLRB decision turning on evidentiary inferences is not altogether immune from judicial review, but it may be overturned only when a court determines that the findings of the agency with respect to questions of fact are not supported by "substantial evidence."22 Pursuant to this statutory mandate, the courts have denied enforceinent to Board orders when the Board has rehed on circuunstantial evidence that is not "substantial," ferences deemed either "unreasonable"24 or "clearly in error." Orders of the NLRB have occasionally been denied enforcement when the trial examiner's drawing of inferences has been rejected by the Board. ${ }^{28}$

(10th Cir. 1969); NLRB v. Power Equip. Co., 313 F.2d 438, 441 (6th Cir. 1963) ("As a reviewing court, we are not free to draw this latter inference, even though we may think it the more logical and might do so were we hearing the case de novo."); NLRB v. Minnesota Mining \& Mfg. Co., 179 F.2d 323, 325 (8th Cir. 1950); NLRB v. Austin Co., 165 F.2d 592, 596 (7th Cir. 1947). See also 4 Davis $\S 29.05$ (1958).

19. 29 U.S.C. $\S 160(e)(1970)$.

20. Id.

21. Universal Camera Corp. v. NLRB, 340 U.S. 474, 488 (1951). See also 62 COLUM. L. REv. 1330 (1962).

22. 29 U.S.C. $\$ 160(\mathrm{e})$ (1970). See generally 4 DAVIS $\$ 29.02, .05, .06$ (1958).

23. NLRB v. Stafford, 206 F.2d 19 (8th Cir. 1953). See also Peoples Motor Exp. v. NLRB, 165 F.2d 903 (4th Cir. 1948).

24. NLRB v. Sunset Minerals, Inc., 211 F.2d 224, 226 (9th Cir. 1954); Tampa Times Co. v. NLRB, 193 F.2d 582, 583 (5th Cir. 1952).

25. United States Steel Co. v. NLRB, 196 F.2d 459, 465 (7th Cir. 1952). See Cooper, Administrative Lav: The "Substantial Evidence" Rule, 44 A.B.A.J. 945, 949 (1958).

26. Southwest Latex Corp. v. NLRB, 426 F.2d 50 (5th Cir. 1970); Cain's Cof- 
There are, however, several countervailing factors which weigh heavily in favor of affirming an agency decision concerning an adverse inference. First, an administrative body which deals in a single, specialized field is presumed to be more qualified to inake findings of fact within that area. ${ }^{27}$ Second, an agency decision is based directly upon first-hand knowledge of a case, and often upon direct contact with the parties involved; ${ }^{28}$ in contrast, both the first-hand knowledge and contact are lacking when an appellate court views the bare record. The third factor weighing in favor of affirming an agency decision concerning an adverse inference is comity-the practical principle of not encouraging undue judicial interference with agencies and the administrative process. ${ }^{29}$ In addition, al-

fee Co. v. NLRB, 404 F.2d 1172 (10th Cir. 1968). See also NLRB v. Neuhoff Bros. Packers, Inc., 398 F.2d 640, 644 (5th Cir. 1968).

Courts have also upheld the Board's rejection of the trial examiner's drawing of inferences. NLRB v. Central Mach. \& Tool Co., 424 F.2d 542 (10th Cir. 1970); AFL-CIO v. NLRB, 420 F.2d 1296 (D.C. Cir. 1969); Rocky Mountain Natural Gas Co. v. NLRB, 326 F.2d 949 (10th Cir. 1964).

In Brief for Petitioner at 10, UAW v. NLRB, 459 F.2d 1329 (D.C. Cir. 1972), it was stated:

Indeed Board decisions have been set aside on review where the adverse

inference was not drawn. NLRB v. Ohio Calcium Co., 133 F.2d 721,

727 (CA 6, 1943); NLRB v. Ford Radio \& Mica Corp., 258 F.2d 457, 463

(CA 2, 1958); NLRB v. Tennessee Consolidated Coal Co., 307 F. 2d 374,

378 (CA 6, 1962); cf. NLRB v. Selwyn Shoe Manu. Corp., 428 F.2d 217, 225-26 (CA 8, 1970).

A careful examination of these cases reveals, however, that in none of the cases was the failure to draw the inference the cause for the setting aside of the Board decision.

27. Radio Officers' Union v. NLRB, 347 U.S. 17, 49 (1954); Universal Camera Corp. v. NLRB, 340 U.S. 474, 488 (1951). See also W. GELlHoRN, FEDERAL ADministrative Proceedings 87 (1941); Jaffe, Judicial Review: Question of Fact, 69 HARv. L. REv. 1020, 1038-40 (1956).

28. Universal Camera Corp. v. NLRB, 340 U.S. 474, 496 (1951); American Brake Shoe Co. v. NLRB, 244 F.2d 489, 493 (7th Cir. 1957). In an unfair labor practice proceeding, the trial exaniner conducts the hearing on the complaint, rules on motions and the admissibility of evidence, sees documentary evidence, and hears the examination and cross-examination of witnesses. 1 B. WERNE, supra note 5, $\S 8.5$.

The Board, in contrast, makes its findings, conclusion, and order on the basis of the record, the trial examiner's decision and recommended order, the exceptions to the trial examiner's decision and order, and the supporting briefs of the parties. Id. \& 8.7.

For discussion of the effect of disagreement between the Board and the trial examiner who has observed the witnesses and lived with the case, see Cooper, supra note 25 , at 1002 .

29. See, e.g., McKart v. United States, 395 U.S. 185, 193 (1969). See also 4 Davis $\$ 28.21$ (1958). 
though courts have previously upheld the use of adverse inferences drawn by triers of fact in agency proceedings ${ }^{30}$-as well as in civil cases $^{31}$ - and while the adverse inference rule has been applied by the Board in cases factually similar to $U A W v . N L R B,{ }^{32}$ no court previous to $U A W$ had compelled the agency to draw an adverse inference. Finally, as the dissent points out, ${ }^{33}$ there is some authority indicating that, at least in civil law cases, the failure of the finder of fact to draw an adverse inference is discretionary and thus not an error reviewable on appeal. ${ }^{34}$

In $U A W$ v. $N L R B,{ }^{35}$ with one judge dissenting in part, the Court of Appeals for the District of Columbia Circuit ordered the NLRB to draw an adverse inference from the employer's failure to produce relevant evidence in an unfair labor practice proceeding. The court also ordered that the company's cost-cutting defense be stricken if subpoenaed hiring records were not produced within 30

30. Bradley v. United States, 322 F. Supp. 369 (D. Alaska, 1971); Smyth v. United States Civil Serv. Comm'n, 291 F. Supp. 568 (E.D. Wis. 1968).

31. Interstate Circuit, Inc. v. United States, 306 U.S. 208, 225-26 (1939); Glimco v. Commissioner, 297 F.2d 537, 540-41 (7th Cir.), cert. denied, 393 U.S. 981 (1968); Daniel v. United States, 234 F.2d 102, 106 (5th Cir. 1956).

32. NLRB v. Drennon Food Prods. Co., 272 F.2d 23 (5th Cir. 1959); WelcomeAmerican Fertilizer Co., 169 N.L.R.B. 862 (1968).

33. 459 F.2d at 1349.

34. See Aetna Cas. \& Sur. Co. v. Smith, 127 A.2d 556 (D.C. Mun. App. 1956). In Aetna, a used car business operator brought an action against his insurer for indemnification for loss of an automobile taken from him but failed to introduco records to substantiate his claim as to the value of the automobile. The insurer contended that the failure to produce records gave rise to a conclusive presumption that the records were unfavorable to the operator. In affirming a judgment against the insurer, the court stated that:

Assuming there was sufficient foundation for an unfavorable inference of this kind, the fact that the trial court failed to draw the inference constitutes no error reviewable on appeal. The inference arising from the refusal or unexplained failure to produce relevant documentary evidence is permissive in nature, and is merely another factor which may be given consideration by the trier of facts when weighing the evidence and determining the credibility of witnesses. Id. at 559 (emphasis added).

The court again noted:

The trial court could have drawn an unfavorable inference, but it was not required to do so and apparently chose not to. Failure of the trier of facts to draw an inference, permissible in nature, cannot be advanced to an appellate court as a ground justifying reversal of the judgment. Id.

See also Gosch v. Gomez, 450 P.2d 1016 (Colo. 1969), where the court, in affirming a judgment to dismiss a claim against an estate, stated:

It is the peculiar responsibility of the trial judge to determine what inferences should be reasonably drawn from the evidence lie hears, and the drawing of or the refusal to draw inferences by a trial judge will not be disturbed by us unless reasonable minds could not differ on the result. Id. at 1017 .

35. 459 F.2d 1329 (D.C. Cir. 1972). 
days. ${ }^{38}$ After setting out the adverse inference rule, ${ }^{37}$ the majority opinion noted the propriety of utilizing the rule in this particular fact situation. ${ }^{38}$ The $U A W$ majority, indicating that the reasons for the Board's refusal to draw the inference were unsatisfactory and irrational, ${ }^{39}$ noted that common sense alone would suggest that one who defies a subpoena to produce records, absent a showing of adequate justification, is withholding adverse evidence from the trier of fact. ${ }^{40}$ However, although the court cited case precedent to indicate that judicial intervention is necessary and proper to insure a "fair hearing,"41 the majority opinion not only failed to cite specific authority for ordering an adverse inference drawn, but also failed adequately to refute the contention that an adverse inference was a discretionary device. ${ }^{42}$ Buttressing its decision to order the drawing of the inference by noting that nothing would be gained by further remand ${ }^{43}$ and that the case had already been held up in seven years of litigation, ${ }^{44}$ the court commented summarily that it is sometimes necessary for a reviewing court to "take direct action" in response to irrational or arbitrary administrative conduct. ${ }^{45}$

$U A W v . N L R B$ is both significant and troublesome. As noted, the $U A W$ court is apparently the first court to have expressly and affirmatively ordered the NLRB to draw an adverse inference. In so doing, the court did not effectively come to grips with the es-

36. Id. at 1347-48. It should be noted that the orders could, depending upon the employer's subsequent actions, be conflicting. If the records are produced, it would be unnecessary to draw an inference.

37. Id. at 1335-36.

38. Id. at $1340-42$.

39. Id. at 1341 ("reasons . . . range from unconvincing to trivial"); id. at 1342 ("none of these reasons will withstand even cursory analysis"); id. at 1346 ("is supported by no reason"); id. ("administrative agencies are not authorized to act arbitrarily and capriciously and that they, unlike juries, are required to give rational reasons for their decisions").

40. Id. at 1338.

41. Id. at 1341 .

42. After noting the Board's argument that the adverse inference was "permissive only," the court cited its prior opinion in the case, 419 F.2d 686 (D.C. Cir. 1969), as inıplicitly holding that the rule was not permissive. (In that opinion, the court remanded to the Board for an explanation of why the inference was not drawn.) The court went on to say that "[m] ore fundamentally," an administrative agency must not act arbitrarily and must give rational reasons for its decisions. Id. at 1346. This would seein to be, at best, a bootstrap argument.

43. Id. at 1347 .

44. Id. at 1348 .

45. Id. at 1347 . 
tablished view that an adverse inference is permissive and the drawing of inferences is within the discretion of the NLRB, not the courts. In apparent disregard of the usual rule that a trial examiner's findings accepted by the Board concerning the credibility of witnesses is to be especially respected, ${ }^{46}$ the $U A W$ majority cursorily rejected the agency's determination that the employer's testimony was trustworthy and reliable. Since the trial examiner accepted the employer's testimony and the Board adopted the examiner's proposed opinion, ${ }^{47}$ the Board's determination on the inatter of credibility should not have been so lightly disregarded. ${ }^{48}$ Nevertheless, the court of appeals' decision reversing the NLRB and ordering the adverse inference may be regarded as correct, since the majority opinion effectively rebutted the generally unsatisfactory reasoning utilized by the Board in determining not to draw the inference. Basing its refusal to draw the adverse inference primarily on the credibility of the employer, ${ }^{49}$ the Board had lent little weight to the fact that it was the same employer who defied an administrative subpoena to produce the records about which he testified. The failure of the employer to produce relevant records in defiance of a subpoena and without explanation would seein sufficient in and of itself to warrant the use of an adverse inference. The question which remains, lowever, is whether $U A W$ is simply an isolated instance of a court straming to reach an equitable decision in an unusual and limited factnal setting. ${ }^{50}$ If it is not, the enunciation of

46. NLRB v. Bendix Corp., 299 F.2d 308 (6th Cir. 1962); NLRB v. Marcus Trucking Co., 286 F.2d 583 (2d Cir. 1961); NLRB v. C. Malone Trucking, Inc, 278 F.2d 92 (1st Cir. 1960). But see NLRB v. Mt. Veruon Tel. Corp., 352 F.2d 977 (6th Cir. 1965). See also note 28 supra.

47. Gyrodyne Co. of America, Inc., 185 N.L.R.B. No. 133, 75 L.R.R.M. 1238 (1970) (supplemental decision).

48. In NLRB v. Dimion Coil Co., 201 F.2d 484, 490 (2d Cir. 1952), the court of appeals commented:

we surely may not upset the Board when it accepts a finding of an Examiner which is grounded upon ... [the] Examiner's evaluation of oral testimony as rehiable, unless on its face it is hopelessly incredible .... See generally Jaffe, supra note 27 . For insight into the relationship between the trial examiner and the NLRB, see 1 B. WERNE, supra note 5 , \$ 8.7; M. MANOFF, LABOR RELATIONS LAW 136-37 (3d ed. 1958). See also note 28 supra.

49. Gyrodyne Co. of America, Inc., 185 N.L.R.B. No. 133, 75 L.R.R.M. 1238, 1239 (1970) (supplemental decision).

50. The case had been in court for seven years. In commenting on this delay, Judge Wright, speaking for the majority, commented caustically:

Once in a great while, a case comes before this court which makes one wonder whether the judicial system is still equipped to deal with a litigant determined to frustrate the workings of justice. Unfortunately, this is such a case. ... The time has come to stop Gyrodyne from accruing interest 
more specific guidelines for affirmatively requiring administrative agencies to draw adverse inferences is essential in order to avoid encroachment, by the judiciary, upon the agency fact-finding function and, ultimately, erosion of the agencies' decision-making authority.

on its investment in intransigence. $459 \mathrm{~F} .2 \mathrm{~d}$ at 1332.

Judge Wright also indicated that the decision was "inotivated in part by the need to bring the seemingly endless years of litigation surrounding this case to a rapid conclusiou." Id. at 1347 . 